\title{
Correction to: TdPm60 identified in wild emmer wheat is an ortholog of $P m 60$ and constitutes a strong candidate for PmG16 powdery mildew resistance
}

\author{
Yinghui $\mathrm{Li}^{1,2} \cdot$ Zhen-Zhen Wei $^{1,2,5} \cdot$ Andrii Fatiukha $^{1,2,6} \cdot$ Samidha Jaiwar ${ }^{1,2} \cdot$ Hanchao Wang $^{1,2} \cdot$ Samiha Hasan ${ }^{1,2}$. \\ Zhiyong Liu $^{3,4} \cdot$ Hanan Sela ${ }^{1}$ (C) Tamar Krugman ${ }^{1} \cdot$ Tzion Fahima $^{1,2}$ (i)
}

Published online: 7 July 2021

(c) The Author(s), under exclusive licence to Springer-Verlag GmbH Germany, part of Springer Nature 2021

\section{Correction to: Theoretical and Applied Genetics https://doi.org/10.1007/s00122-021-03858-3}

Unfortunately, the title of the last part in the Results section contained a mistake in the original publication. The correct heading reads: Introgression of PmG16 into hexaploid wheat.

The original article has been corrected.

Publisher's Note Springer Nature remains neutral with regard to jurisdictional claims in published maps and institutional affiliations.

The original article can be found online at https://doi.org/10.1007/ s00122-021-03858-3.

Tzion Fahima

tfahima@evo.haifa.ac.il

1 Institute of Evolution, University of Haifa, Mt. Carmel, 3498838 Haifa, Israel

2 The Department of Evolutionary and Environmental Biology, University of Haifa, Mt. Carmel, 3498838 Haifa, Israel

3 State Key Laboratory of Plant Cell and Chromosome Engineering, Institute of Genetics and Developmental Biology, The Innovative Academy of Seed Design, Chinese Academy of Sciences, Beijing 100101, China

4 University of Chinese Academy of Sciences, Beijing 100049, China

5 Present Address: Department of Agronomy, the Key Laboratory of Crop Germplasm Resource of Zhejiang Province, Zhejiang University, Hangzhou 310058, Zhejiang, China

6 Present Address: Crop Developmental Centre and Department of Plant Sciences, University of Saskatchewan, Saskatoon, SK S7N 5A8, Canada 